\title{
Relative importance of phototrophic, heterotrophic, and mixotrophic nanoflagellates in the microbial food web of a river-influenced coastal upwelling area
}

\author{
Cristian A. Vargas $^{1, *}$, Paulina Y. Contreras ${ }^{1}$, José Luis Iriarte ${ }^{2}$ \\ ${ }^{1}$ Aquatic Systems Research Unit, Environmental Sciences Center EULA Chile, Universidad de Concepción, PO Box 160-C, \\ Concepción, Chile \\ ${ }^{2}$ Instituto de Acuicultura, Facultad de Pesquerías y Oceanografía, Universidad Austral de Chile, PO Box 1327, Puerto Montt, Chile
}

\begin{abstract}
The contribution of phototrophic nanoflagellates (PNF) as primary producers and heterotrophic (HNF) and mixotrophic (MNF) nanoflagellates as major grazers of bacterioplankton was assessed during a 3 yr study in a highly productive, river-influenced coastal upwelling area under contrasting seasons (winter/non-upwelling vs. spring/upwelling). Sampling was conducted at 2 stations - around a river plume and at an intensive seasonal upwelling site - with contrasting environmental gradients. The MNF were evaluated functionally for the possession of photo-pigments and experimentally for the ability to take up prey, specifically fluorescently labeled bacteria (FLB). During the short-term experiments, we estimated grazing rates over FLB for 2 size categories of $\mathrm{HNF}$ and MNF. Both bacterial production (BP) and nanophytoplankton primary production (PP) were higher in the river plume area. PNF abundance ranged from $6 \times 10^{9}$ to $411 \times 10^{9}$ cells m$^{-2}$,

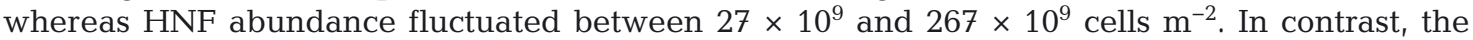
abundance of MNF was usually low, with a maximum of $\sim 7 \times 10^{9}$ cells m$^{-2}$. For MNF, ingestion rates were between 7.3 and 30.7 bacteria per flagellate and hour (bact flag ${ }^{-1} \mathrm{~h}^{-1}$ ), whereas HNF ingestion ranged from 2 to 7.5 bact flag $^{-1} \mathrm{~h}^{-1}$. However, since HNF dominated in terms of abundance, they were the dominant grazers on bacterioplankton populations. Estimates of grazing pressure for the microbial food web showed that MNF were capable of removing 1 to $51 \% \mathrm{BP} \mathrm{d}^{-1}$, whereas HNF could control BP, eliminating from $24 \% \mathrm{BP} \mathrm{d}^{-1}$ up to more than $100 \% \mathrm{BP} \mathrm{d}^{-1}$. Given the area's relatively high nutrient condition, the elevated MNF biomass in the river plume and the greater bacterivory impact from MNF in winter, it seems that light and, thus, the energy/carbon limitation could be the main trigger for mixotrophy in this river-influenced coastal upwelling area.
\end{abstract}

KEY WORDS: Mixotrophy $\cdot$ River discharge $\cdot$ Upwelling area $\cdot$ Plankton food web

\section{INTRODUCTION}

Protozoan nanoflagellates are ubiquitous members of planktonic food webs in both freshwater and marine aquatic ecosystems (Laybourn-Parry \& Parry 2000). This group of small organisms encompasses a wide range of nutritional types, including purely photosynthetic cells, different degrees of mixotrophy, and heterotrophs, which consume mostly bacteria and small algal cells (González et al. 1990, Sherr \&
Sherr 1994). The importance of bacterivorous nanoflagellates in planktonic food web dynamics and biogeochemical cycles has been recognized since the works by Pomeroy (1974) and Azam et al. (1983). By then, the traditional classical food web concept (phytoplankton-zooplankton-fishes) incorporated the major top-down role of prokaryotes and different protists into a 'microbial food web'. In this food web, about 40 to $60 \%$ of the carbon fixed by primary producers is thought to pass through heterotrophic 
bacterioplankton (Cole et al. 1988) rather than directly into herbivorous zooplankton. This bacterial biomass is controlled by mortality through viral infection as well as grazing by both heterotrophic (HNF) and mixotrophic nanoflagellates (MNF), especially in oligotrophic environments (Christaki et al. 1999). Furthermore, grazing by HNF and MNF may commonly balance bacterial production (BP) (Andersen \& Fenchel 1985). Nanoflagellates may, in turn, transfer bacterial or small algal carbon indirectly to larger protozoans (ciliates and dinoflagellates) and/ or directly to mesozooplankton grazers (Vargas et al. 2007, 2010), which would indeed strengthen the link between the microbial and classical food webs, increasing the trophic efficiency of the microbial loop (Sanders 1991).

Recent research has demonstrated the widespread occurrence of mixotrophy as a significant mode of nutrition in both freshwater (e.g. Bennett et al. 1990) and marine nanoflagellate communities (e.g. Unrein et al. 2007). MNF forms are able to combine phototrophic nutrition with the uptake of particulate or dissolved organic material (Sanders 1991). The occurrence and high clearance rates of MNF (e.g. Bennett et al.1990, Czypionka et al. 2011) suggest that they might contribute substantially to total bacterivory in aquatic ecosystems. Furthermore, photosynthesis by MNF may also contribute to primary production in the nanoplankton size fraction in coastal areas (Marshall \& Laybourn-Parry 2002, Jost et al. 2004).

Mixotrophy has been suggested to be a nutritional strategy for algal cells during low nutrient conditions (Jost et al. 2004), which are not common at productive coastal upwelling sites (Vargas et al. 2007). Hence, the ecological role of mixotrophy has not been incorporated into carbon fluxes and food web models for these productive coastal environments and is probably underappreciated at the moment. Although bacterivory by both HNF and MNF is likely to play a major role in channeling bacterial production to higher trophic levels in situations of coastal environmental gradients, field studies contrasting the role and impact of MNF during different seasons are scarce for marine ecosystems (e.g. Tsai et al. 2007, Unrein et al. 2007). These studies can be relevant for estuarine and river-influenced areas where the flux of dissolved organic matter from freshwater runoff may be significant and bacterial biomass and production are relatively high (Dagg et al. 2004).

The incorporation of mixotrophy into food web models of highly productive, temperate coastal areas requires a robust data set with precise estimations of the nanoflagellate grazing impact on bacterioplankton, as opposed to a data set of strictly heterotrophs over contrasting seasons (spring vs. winter) and environmental gradients (e.g. upwelling vs. river discharges). During this study, we experimentally investigated the nanoflagellate alga community in winter and spring, asking one simple question: Is mixotrophy a significant strategy ( $>20 \%$ of total bioamss) in this highly-productive, temperate coastal upwelling area? We determined the relative importance of phototrophic nanoflagellates (PNF) as phytoflagellate primary producers and the relevance of HNF and MNF as major grazers of bacterioplankton in a productive, river-influenced coastal upwelling area. Although 'mixotrophy' describes many forms of nutritional strategies on the continuum from absolute phototrophy to absolute heterotrophy, we used this word to refer to algae combining phototrophic and phagotrophic heterotrophy. Mixotrophy was evaluated functionally by the possession of photo-pigments and experimentally by the ability to take up prey (i.e. fluorescently labeled bacteria, FLB).

\section{MATERIALS AND METHODS}

\section{Study area}

The river-influenced coastal upwelling area off Concepción, central Chile $\left(36^{\circ} \mathrm{S}\right)$, is located on one of the widest parts of the continental shelf along the eastern boundary coastal upwelling margin. This area also receives freshwater discharges from 2 important rivers: the Itata River (mean flow: $296 \mathrm{~m}^{3}$ $\mathrm{s}^{-1}$ ) and the Bío-Bío River (mean flow: $1699 \mathrm{~m}^{3} \mathrm{~s}^{-1}$ ). The runoff from these rivers supplies the coastal ocean with substantial amounts of silicate, nitrate, and phosphate as well as trace metals (Sánchez et al. 2008). This area is characterized by seasonal upwelling events in austral spring-summer (Vargas et al. 2007), when upwelling-driven phytoplankton blooms, which are typically dominated by longchain-forming diatoms, occur in the shallow embayment (Vargas et al. 2007) and result in one of the highest primary production (PP) rates ( 4 to $20 \mathrm{~g} \mathrm{C}$ $\mathrm{m}^{-2} \mathrm{~d}^{-1}$ ) reported worldwide for coastal areas (Montero et al. 2007). Two nearshore stations with contrasting environmental gradients (maximum depth: $40 \mathrm{~m}$ ) were established off the coast of central Chile. One station (Stn RV) was located around the plume of the Itata River and the other (Stn UW) approximately $20 \mathrm{~km}$ southeast of Coliumo Bay, in an area of intensive seasonal upwelling events (Fig. 1). The 
selection of these stations was based in terms of the major driver for nutrient input in the euphotic zone (river discharge vs. coastal upwelling).

\section{Seawater sampling and hydrography}

Samples were taken during seven $2 \mathrm{~d}$ cruises aboard the LC 'Kay Kay' (Universidad de Concepción) in spring/summer and winter as part of the OMMIX Project (influence of OMnivory and MIXotrophy in food-web dynamic). Field sampling was conducted twice in December 2006 (spring), June 2007 (winter), and December 2007 (spring), and once in August 2008 (winter). At each station, temperature, salinity, oxygen, and fluorescence profiles were recorded from near the bottom to the surface using a SeaBird SBE-19 plus CTD equipped with a YSI-calibrated Beckman oxygen sensor and a Wetstar fluorometer. Water samples (1 l l) for PNF and HNF abundance and biomass were collected at discrete depths $(1,5,10,25$, and $35 \mathrm{~m})$ with a rosette system equipped with twelve 81 Niskin bottles. Nanoplankton samples were preserved in glutaraldehyde $(2.0 \% \mathrm{w} / \mathrm{v}$ in $0.2 \mu \mathrm{m}$ prefiltered seawater). Additional samples for nutrient concentrations and short-term grazing experiments (5 l) were also collected from the surface, maximum fluorescence depth, and the base of the thermocline (see 'Short-
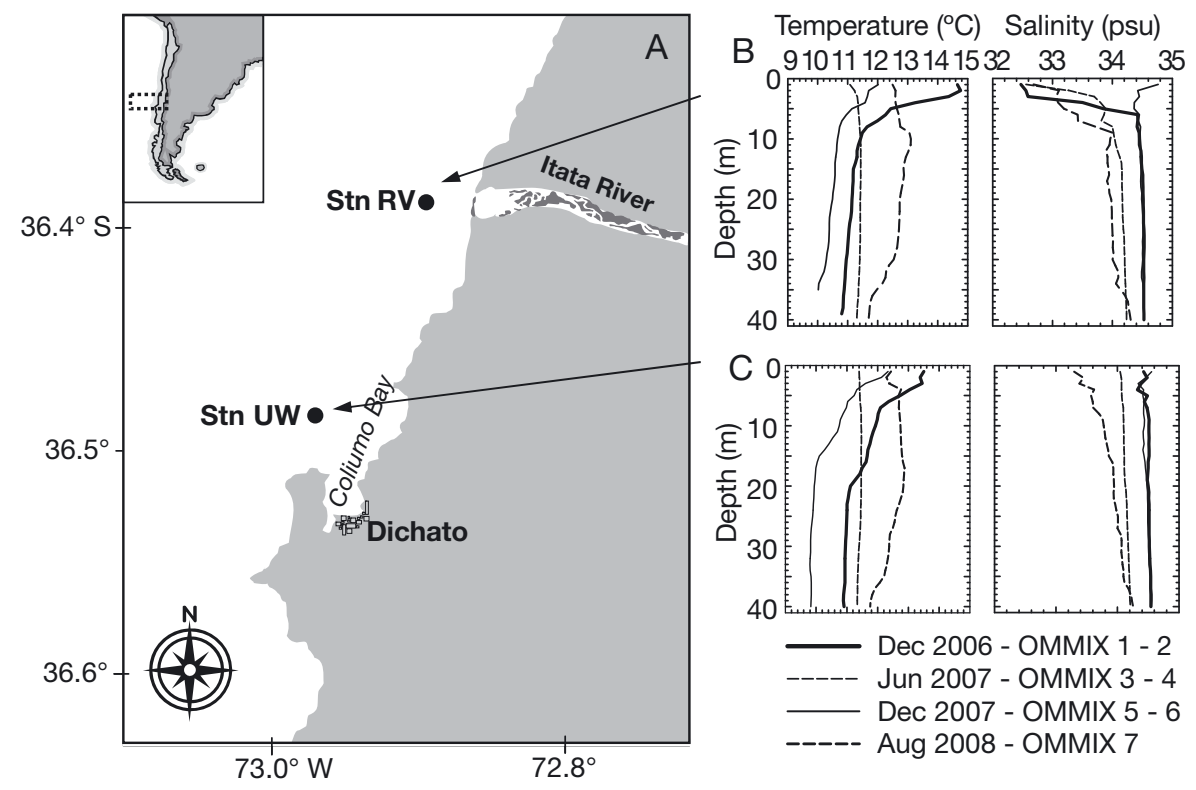

Fig. 1. (A) Study area and locations of the sampling stations in the Itata River plume area (Stn RV) and upwelling site off Coliumo Bay (Stn UW), including seasonal averages of temperature $\left({ }^{\circ} \mathrm{C}\right.$ ) and salinity (psu) at (B) Stn RV and (C) Stn UW during OMMIX cruises 1 to 7 term grazing experiments' below). Samples for nutrient analysis, including nitrate $\left(\mathrm{NO}_{3}{ }^{-}\right)$, nitrite $\left(\mathrm{NO}_{2}{ }^{-}\right)$, and phosphate $\left(\mathrm{PO}_{4}{ }^{3-}\right)$, were filtered (GF/F filters) on board and frozen $\left(-20^{\circ} \mathrm{C}\right)$ until analysis in the laboratory. $\mathrm{NO}_{3}{ }^{-}$and $\mathrm{PO}_{4}{ }^{3-}$ were determined spectrophotometrically following Strickland \& Parsons (1968). $\mathrm{NO}_{2}{ }^{-}$was analyzed using an automated nutrient analyzer (ALPKEM, Flow Solution IV) following the protocol of the US Environmental Protection Agency; Method 353.2. River flow data were obtained from the National Water Directorate (www.dga.cl), whereas PAR (photosynthetically active radiation) time-series were obtained from a HOBO weather station (Onset Computer Corp., USA) installed by the COPAS Center (Universidad de Concepcion) at $36^{\circ} 31.687^{\prime} \mathrm{S}$ and $72^{\circ} 57.955^{\prime} \mathrm{W}$.

\section{Bacterioplankton and nanoplankton abundance and biomass estimates}

The abundances of bacteria and cyanobacteria were estimated by flow cytometry. Samples of $1350 \mu \mathrm{l}$ were collected in $1500 \mu \mathrm{l}$ vials, fixed with paraformaldehyde ( $1 \%$ final concentration) and quickfrozen in liquid nitrogen. Subsamples of $150 \mu \mathrm{l}$ were processed on a FACSCalibur flow cytometer equipped with an Ion-Argon Laser of $488 \mathrm{~nm}$ and $15 \mathrm{MW}$ (Becton Dickinson). Coccoid cyanobacteria (Synechococcus) and photosynthetic eukaryotes were distinguished by differences in side light scatter and by fluorescence in the orange (cyanobacteria) and red (eukaryotes) wavelengths. Heterotrophic bacteria abundance was obtained from samples previously stained with SYBR Green I (Molecular Probes) (Marie et al. 1997). The bacterial volume was calculated from length and width measurements of at least 20 cells per sample using standard geometric forms for a sphere and an ellipsoid (i.e. rods and bacilli), respectively. Finally, the volume-tocarbon conversion was carried out using a factor of $0.35 \mathrm{pg} \mathrm{C} \mathrm{m}^{-3}$ (Bjørnsen 1986).

Nanoflagellates were quantified by the proflavine technique (Haas 1982). For the enumeration of nanoflagellates, subsamples were filtered on a $0.8 \mu \mathrm{m}$ polycarbonate membrane filter, stained with proflavine 
$(0.033 \% \mathrm{w} / \mathrm{v}$ in distilled water) following Haas (1982), and fixed with glutaraldehyde (as above) for subsequent analysis. Nanoflagellates were counted with an inverted microscope OLYMPUS IX-51 equipped with UV model UMWU2 (width band pass 330 to $385 \mathrm{~nm}$ ) and FITC model U-MWB2 (width band pass 450 to $480 \mathrm{~nm}$ ) filter sets. Nanoflagellates were measured and their biovolume was estimated from a minimum of 80 cells per group (PNF, MNF, and HNF). Nanoflagellate counts considered 2 major size classes: $<5 \mu \mathrm{m}$ and 5-20 $\mu \mathrm{m}$, with a mean volume of $11.7( \pm 0.5)$ and $47.6( \pm 2.8) \mu \mathrm{m}^{3}$ for each size class. Biomass was estimated using a size-dependent carbon:volume ratio as suggested by Verity et al. (1992). The trophic mode of nanoflagellates (phototrophic, heterotrophic, and/or mixotrophic) was assessed by estimating the FLB uptake during a short-term incubation (see 'Short-term grazing experiments' below).

\section{Nanoplankton primary production and bacterial production}

Water samples for PP estimates were collected in a 5.01 PVC Go-Flo bottle (General Oceanics) at 4 depths: $0 \mathrm{~m}$, maximum fluorescence depth (ca. $28 \%$ of surface irradiance), the thermocline base (i.e. halocline base in winter, ca. $51 \%$ of surface irradiance), and $20 \mathrm{~m}$ (ca. $2 \%$ surface irradiance). Samples were incubated in $125 \mathrm{ml}$ polycarbonate bottles (2 clear +1 dark bottle) and placed in a natural-light incubator for ca. 4 h (roughly 10:00 to 14:00 h). Running surface seawater over the incubation bottles regulated ambient temperature and light intensity was attenuated using a screen (i.e. nylon fibers matrix, gray colour) to approximate light at the depth where the water was collected (Iriarte \& González 2004). Radiolabeled sodium bicarbonate (30 to $40 \mu \mathrm{Ci} \mathrm{NaH}{ }^{14} \mathrm{CO}_{3}$ ) was added to each bottle. Primary production was measured using the method described by SteemannNielsen (1952). Samples were manipulated under subdued light conditions during pre- and post-incubation periods. Filters $(0.7 \mu \mathrm{m})$ were placed in $20 \mathrm{ml}$ plastic scintillation vials and kept at $-15^{\circ} \mathrm{C}$ until reading (15 d later). To remove excess inorganic carbon, filters were treated with $\mathrm{HCl}$ fumes for $24 \mathrm{~h}$. A cocktail ( $8 \mathrm{ml}$, Ecolite) was added to the vials and radioactivity was determined in a Beckmann scintillation counter. Differential size fractionation of phytoplankton to determine nanoplankton PP and chlorophyll a (chl a) was carried out by pre-filtering the seawater samples using a $20 \mu \mathrm{m}$ Nitex mesh. The filtrate was then collected on a $2.0 \mu \mathrm{m}$ Nuclepore polycarbonate filter. Water samples for chl a measurements were taken at the same depths as the samples collected for PP analysis. Seawater samples $(200 \mathrm{ml})$ were filtered following the same procedure used for PP, extracted in $90 \% \mathrm{v} / \mathrm{v}$ acetone, and analyzed using a digital PS-700 Turner fluorometer (Parsons et al. 1984). Depth-integrated nanoplankton PP and chl a values through the photic layer were estimated by the trapezoidal integration method.

The ambient BP was estimated from the L- $\left[{ }^{14} \mathrm{C}(\mathrm{U})\right]-$ leucine incorporation rates (Simon \& Azam 1989). From each depth, $10 \mathrm{ml}$ of seawater from each depth were transferred to sterile tubes (3 replicates and 1 blank). The blank was poisoned with $0.2 \mu \mathrm{m}$ filtered formaldehyde. We added radio-labeled leucine (300 to $330 \mathrm{mCi} \mathrm{mmol}^{-1}$ s.a., Sigma T-6527) to obtain final saturation concentrations of $50 \mathrm{nM}$, which has been already reported as the mean saturation level for the same study area by Hernández et al. (2006). All tubes were incubated in the dark for 1 to $2 \mathrm{~h}$ at the surface in situ water temperature. We also selected the incubation period for both sampling stations considering previous studies in the same coastal region (i.e. Troncoso et al. 2003, Hernández et al. 2006). After incubation, ${ }^{14}$ C-leucine incorporation was stopped by adding $2 \%$ formalin. The samples were extracted with ice-cold trichloroacetic acid (TCA, final conc. of $5 \%$ ) for $15 \mathrm{~min}$. The extracted samples were kept cool, filtered onto $0.45 \mu \mathrm{m}$ cellulose nitrate filters (Whatman), and rinsed 3 times with $5 \mathrm{ml}$ of $5 \%$ icecold TCA. The filters were placed into scintillation vials and dissolved in $1 \mathrm{ml}$ of ethylacetate. A volume of $10 \mathrm{ml}$ of liquid scintillation cocktail (Ecolitel) were added and the samples were radio assayed. Leucine uptake was estimated from dpm using a Packard (Model 1600TR) liquid scintillation counter; counting efficiency was calculated from the non-quenched standard of ${ }^{3} \mathrm{H}$-toluene. BP from leucine incorporation was calculated using a ratio of cellular carbon to protein of 0.86 and a fraction of leucine in protein of 0.073 (Simon \& Azam 1989). The cell production rates, obtained from moles of leucine incorporated (see Furhman \& Azam 1982), were transformed to BP assuming a widely used conversion factor of $2 \times 10^{18}$ (Lee \& Fuhrman 1987).

\section{Short-term grazing experiments}

Seawater samples for short-term grazing experiments were taken from 3 different layers: (a) the maximum fluorescence depth (FMD), (b) thermocline 
base (i.e. halocline base in winter; BT), and (c) a deeper layer $(25 \mathrm{~m}$ depth). Samples were filtered through a $20 \mu \mathrm{m}$ mesh-sized Nitex-net to obtain the nanoplankton fraction, whereon they were left undisturbed for $1 \mathrm{~h}$ at the in situ temperature until setting up the experiment. The functional analysis of the nanoplankton community was done using FLB following the methods of Sherr et al. (1987). FLB uptake experiments were carried out in triplicate in $250 \mathrm{ml}$ acid-cleaned polycarbonate bottles (Nalgene) and incubated in an on-deck rack equipped with a shading device to mimic the in situ temperature and the in situ light regime when necessary. In the assay, FLB were added to a final concentration of $10^{5} \mathrm{FLB} \mathrm{ml}^{-1}$, following Sherr et al. (1987), which in fact represented between 10 to $20 \%$ of the ambient bacterial abundance. Subsamples of $30 \mathrm{ml}$ were collected at $0,10,30$, and $50 \mathrm{~min}$, fixed with glutaraldehyde (final concentration of $2 \%$; Christaki et al. 1999), and stained with a combination of $1200 \mu \mathrm{l}$ of DAPI (diamidino phenylindole; final concentration: $4 \mathrm{\mu g} \mathrm{ml}^{-1}$ ) and $600 \mu \mathrm{l}$ of proflavine (final concentration: $0.033 \%$; Haas 1982). Stained samples were filtered on $0.8 \mu \mathrm{m}$ Nuclepore filters for counting nanoflagellates and stored at $-20^{\circ} \mathrm{C}$ until analysis. Analysis was performed at a magnification of $\times 1000$ with an Olympus IX-51 using one filter (excitation UV-light 340 to $380 \mathrm{~nm}$, emission 43 to 485 $\mathrm{nm}$ ) to observe DTAF (dichlorotriazinyl aminofluorescein) and DAPI fluorescence and a second filter (excitation 450 to $490 \mathrm{~nm}$, emission $515 \mathrm{~nm}$ ) to observe proflavine and chlorophyll auto-fluorescence. At least 250 flagellates per filter were classified according to their size $(2-5$ and $5-20 \mu \mathrm{m})$ and nutritional regime: phototrophic (i.e. chloroplast autofluorescence), heterotrophic (i.e. proflavine stain without autofluorescence), and/or mixotrophic (i.e. chloroplast autofluorescence and FLB-ingestion). Food vacuole content was estimated for both mixotrophic and heterotrophic cells based on their FLB ingestion. Since mixotrophic forms were classified based on their FLB uptake, without consideration of inactive grazers as for HNF forms, ingestion rate was overestimated relative to heterotrophic cells by using this methodology. For both mixotrophs and heterotrophs, the mean food vacuole content was used for clearance estimations. We calculated the number of ingested FLB ind. ${ }^{-1} \mathrm{~h}^{-1}$ from the slope of food vacuole content versus incubation time for each bottle multiplied by the FLB concentration. Average values of ingested FLB ind. ${ }^{-1} \mathrm{~h}^{-1}$ were calculated for triplicate bottles and clearance was measured over the linear portion of the uptake curve. Finally, ingestion rates were calculated by multiplying the clearance rate by the ambient bacterial abundance at the sampling station. Carbon balances were made using data for ingestion rates assuming a gross growth efficiency of $32 \%$ (Straile 1997). Mixotrophs were assumed to be only $50 \%$ as efficient at fixing inorganic carbon as strict autotrophs (Hansen et al. 2000, Adolf et al. 2006). Consequently, cell specific PP was determined by calculating their share of the total nanoplankton PP.

Potential differences in biomasses and production between stations RV and UW were tested for using a randomized paired $t$-test that compared depth-integrated biomass estimates production for each taxonomic group, and bacterial and size-fractioned primary within each season (see Manly 1997). A Spearman's rank correlationbetween MNF and HNF ingestion rates and environmental variables were also conducted on the $\log (x+1)$ transformed data.

\section{RESULTS}

\section{Hydrography}

Values of surface temperature, salinity, and inorganic nutrient concentrations clearly reflected the different physical/chemical environments of the sampling periods (Figs. 1, 2 \& 3A). As typical at this latitude, spring and winter periods showed contrasting scenarios in light conditions (PAR), with values

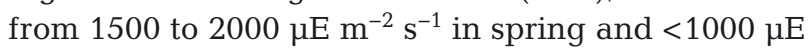

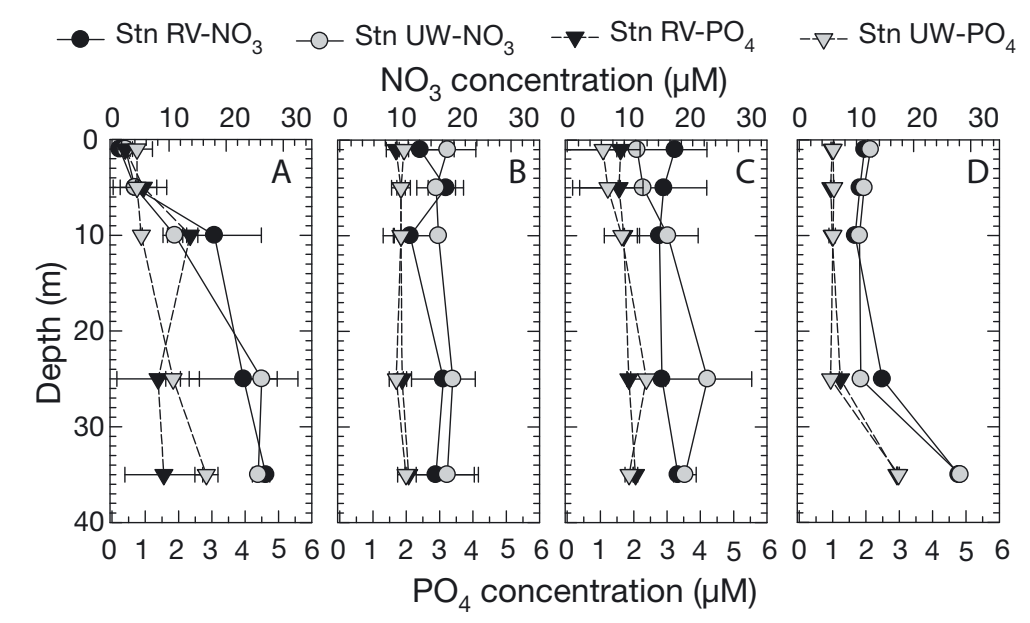

Fig. 2. Concentration (mean $\pm \mathrm{SD}_{i} \mu \mathrm{mol}$ ) of nitrate $\left(\mathrm{NO}_{3}\right)$ and orthophosphate $\left(\mathrm{PO}_{4}\right)$ at both sampling stations and averaged for each sampling season (A: December 2006; B: June 2007; C: December 2007; D: August 2008) 

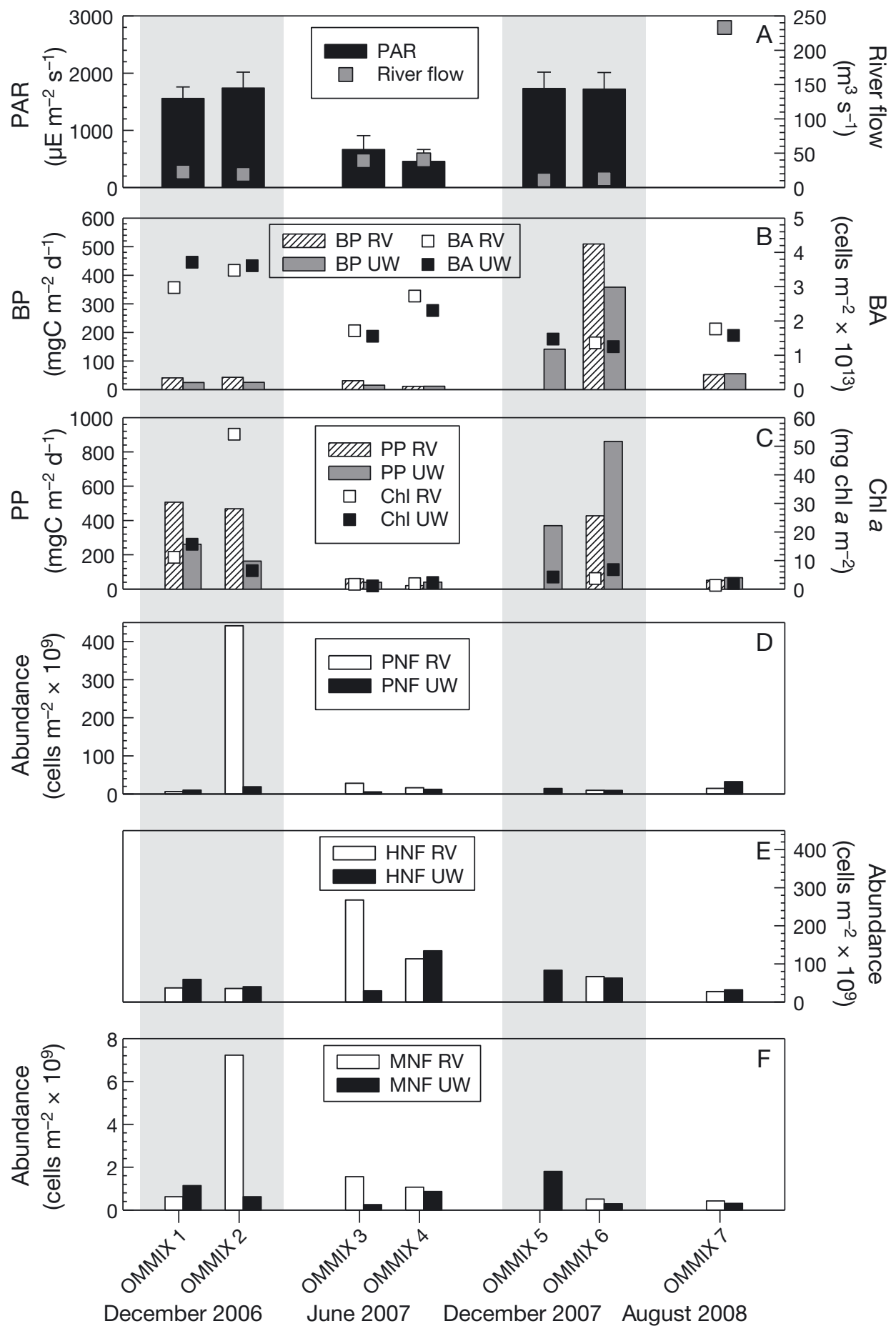

Fig. 3. Seasonal variations (spring vs. winter) of ambient parameters, rates, and abundances evaluated at both sampling stations (Stns RV and UW) during OMMIX cruises 1 to 7: (A) photosynthetically active radiation (PAR) and river flow, (B) upper $20 \mathrm{~m}$ depth-integrated bacterial production (BP) and bacterial abundance (BA), (C) nanophytoplankton primary production (PP) and chlorophyll a biomass (Chl a), and (D-F) abundance of phototrophic (PNF), heterotrophic (HNF) and mixotrophic (MNF) nanoflagellates, respectively. Shaded areas represent spring sampling periods

$\mathrm{m}^{-2} \mathrm{~s}^{-1}$ in winter (Fig. 3A). CTD profiles indicated a well-defined seasonal thermocline located between 3 and $10 \mathrm{~m}$ depth at both sampling stations during the spring periods (OMMIX 1, 2, 5, 6) (Fig. 1). Salinity profiles at Stn RV (Fig. 1) evidenced the influence of the freshwater flow on the hydrographic characteris- 
tics of the surface water column, with a shallow lens of less-saline water located in the upper $5 \mathrm{~m}$, except in spring 2007, when river flow was $<20 \mathrm{~m}^{3} \mathrm{~s}^{-1}$ (Fig. 2A). In spring 2006, the water column showed high thermal and haline stratification, with low nutrient concentrations in the upper $10 \mathrm{~m}$ depth. In spring 2007, $\mathrm{NO}_{3}{ }^{-}$and $\mathrm{PO}_{4}{ }^{3-}$ were not depleted in the surface waters ( $>10$ and $1 \mu \mathrm{M}$, respectively), and higher values were associated with the river plume (Stn RV). In winter, the vertical distribution of nutrients was relatively homogeneous in the upper $25 \mathrm{~m}$ depth, with non-significant differences between stations $(t-$ test: $p>0.05$; Fig. 2B,D).

\section{Bacterioplankton and nanoplankton abundance, biomass and production}

Maximum fluorescence depth was $\sim 10 \mathrm{~m}$ during spring and from 5 to $8 \mathrm{~m}$ depth during winter, and non-significant differences were observed between both sampling stations. The mean bacterial cell volume (0.3 to $0.7 \mathrm{~m}^{3}$ ) did not vary substantially between stations (data not shown). In the upper $20 \mathrm{~m}$, integrated BP ranged between 11 and $509 \mathrm{mg} \mathrm{C} \mathrm{m}^{-2} \mathrm{~d}^{-1}$. During most of the field surveys, BP was relatively low $\left(<60 \mathrm{mg} \mathrm{C} \mathrm{m}^{-2} \mathrm{~d}^{-1}\right)$, and high values $\left(\sim 500 \mathrm{mg} \mathrm{C} \mathrm{m}^{-2}\right.$ $\mathrm{d}^{-1}$, Fig. 3B) were only observed in December 2007 (OMMIX 6). BP was always higher in the river plume area at Stn RV (Fig. 3B), and the highest values of BP were associated with the FMD in spring and with deeper waters in winter ( $25 \mathrm{~m}$ depth; Fig. 4). In contrast, the average BP at Stn UW was higher at the base of the thermocline for all field campaigns. In general terms, bacterial abundance was higher at Stn RV, except in spring 2006. A gross estimation of bacterial growth rate (BGR) (calculated as a ratio of BP over biomass) showed that BGR was always higher at the Stn RV (t-test, $\mathrm{p}<0.01$ ) (data not shown).

Upper $20 \mathrm{~m}$ depth-integrated PP in the nanoplankton size fraction ranged from 20 to $862 \mathrm{mg} \mathrm{C} \mathrm{m}^{-2} \mathrm{~d}^{-1}$, with the lowest values recorded in winter 2007 and the highest in spring 2007 (Fig. 3C). A trend of higher nanophytoplankton PP in the river plume was also observed during the study period, except in spring 2007 (OMMIX 6). Despite extremely high chl $a$ in December 2006 (OMMIX 2) at Stn RV ( 55 mg chl a $\mathrm{m}^{-2}$; Fig. 3C), significant differences were not found at the 2 sampling stations over time ( $t$-test; $\mathrm{p}>0.01)$. A randomized paired $t$-test comparing depth-integrated PP and BP at the 2 sampling stations showed that only BP was substantially different at Stn RV and UW in spring, being higher in the river plume.
Fig. 3D-F shows the integrated abundance of PNF, $\mathrm{MNF}$, and HNF in the upper $20 \mathrm{~m}$ depth. Flagellates $<5 \mu \mathrm{m}$ in size were much more abundant than those between 5 and $20 \mu \mathrm{m}$, whereas heterotrophic forms were more abundant than strictly plastidic ones during most winter periods. PNF abundance varied widely, from $6 \times 10^{9}$ to $411 \times 10^{9}$ cells m ${ }^{-2}$. However, with the exception of a large peak in abundance of small PNF during OMMIX 2 in December 2006 at Stn $\mathrm{RV}$, abundances were commonly $<35 \times 10^{9}$ cells $\mathrm{m}^{-2}$ (Fig. 3D). There was no clear seasonal trend in the abundance of PNF at either sampling site. The HNF abundance ranged between $27 \times 10^{9}$ and $267 \times 10^{9}$ cells $\mathrm{m}^{-2}$, and was highest in winter (July) 2007 at the Stn RV (Fig. 3E). The MNF abundance was usually low, with a maximum of $\sim 7 \times 10^{9}$ cells $\mathrm{m}^{-2}$. Moreover, it broadly reflected the temporal pattern of the PNF abundance, which made the greatest contribution during the peak of PNF in December 2006 (OMMIX 2 ; Fig. 3F). On average, in spring, the highest abundance of PNF, MNF, and HNF was associated with the maximum fluorescence depth $(\mathrm{PNF}=7.8$ to 8.8 cells ml${ }^{-1}, \mathrm{MNF}=0.06$ to 0.2 cells $\mathrm{ml}^{-1}$, and $\mathrm{HNF}=$ 2.4 to $3.5 \mathrm{cells} \mathrm{ml}^{-1}$ ), whereas in winter, these maxima were concentrated toward the bottom of the thermo-

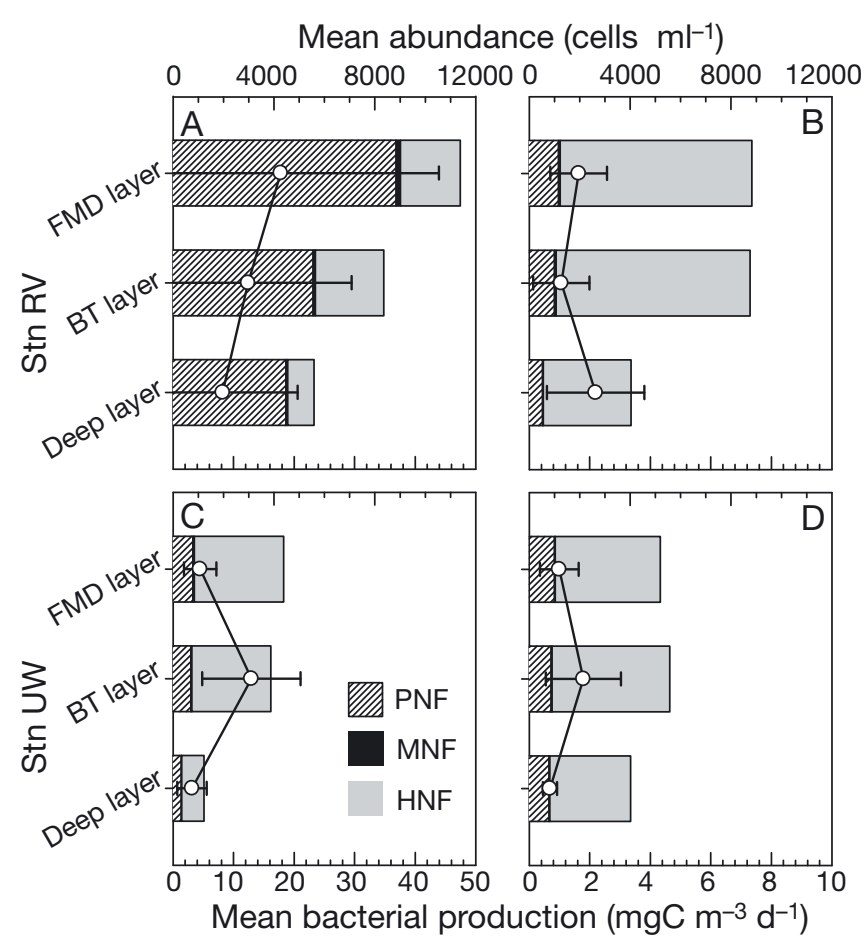

Fig. 4. Vertical distribution of mean $( \pm \mathrm{SD})$ bacterial production $\left(\mathrm{mg} \mathrm{C} \mathrm{m}^{-3} \mathrm{~d}^{-1}\right.$ ) and nanoflagellate abundance (cells $\mathrm{ml}^{-1}$ ) for the 3 categories analyzed (PNF, MNF, $\operatorname{HNF})$ : $(\mathrm{A}, \mathrm{B})$ in the river plume area, Stn RV, and (C,D) off Coliumo Bay, Stn UW, averaged for spring $(A, C)$ and winter $(B, D)$ conditions 
cline (Fig. 4). We did not observe significant differences in integrated biomasses between stations for the different groups of flagellates or for bacteria $(t-$ test; $p>0.01$; Table 1, Fig. 5a), despite the peak in

Table 1. Results of randomized paired $t$-tests comparing depth-integrated biomass and size-fractionated primary production and bacterial production between stations within each season. Significant differences $(\alpha=0.05)$ are shown in bold. Bonferroni-corrected significance levels for multiple biomass and primary production comparisons were $\alpha_{\mathrm{b}}=$ 0.0056 and $\alpha_{p}=0.0167$, respectively. PNF, MNF and HNF: phototrophic, mixotrophic and heterotrophic nanoflagellates, respectively

\begin{tabular}{|c|c|c|c|c|}
\hline \multirow[t]{2}{*}{ Group } & \multicolumn{2}{|c|}{ Spring } & \multicolumn{2}{|c|}{ Winter } \\
\hline & $t$ & $\mathrm{p}$ & $t$ & $\mathrm{p}$ \\
\hline \multicolumn{5}{|l|}{ Biomass $\left(\mathrm{mg} \mathrm{C} \mathrm{m}^{-2}\right)$} \\
\hline Bacteria & -1.13 & 0.757 & 3.53 & $<0.001$ \\
\hline PNF & 0.97 & 0.246 & 13.96 & $<0.001$ \\
\hline MNF & 1.11 & 0.121 & 0.02 & 0.373 \\
\hline HNF & 0.71 & 0.243 & 1.39 & 0.115 \\
\hline \multicolumn{5}{|c|}{ Primary production $\left(\mathrm{mg} \mathrm{C} \mathrm{m} \mathrm{m}^{-2} \mathrm{~d}^{-1}\right)$} \\
\hline Size class $2-20 \mu \mathrm{m}$ & 0.14 & 0.249 & 1.55 & 0.130 \\
\hline \multicolumn{5}{|c|}{ Bacterial production $\left(\mathrm{mg} \mathrm{C} \mathrm{m}^{-2} \mathrm{~d}^{-1}\right)$} \\
\hline Bacterioplankton & 1.21 & 0.024 & 0.05 & 0.950 \\
\hline
\end{tabular}
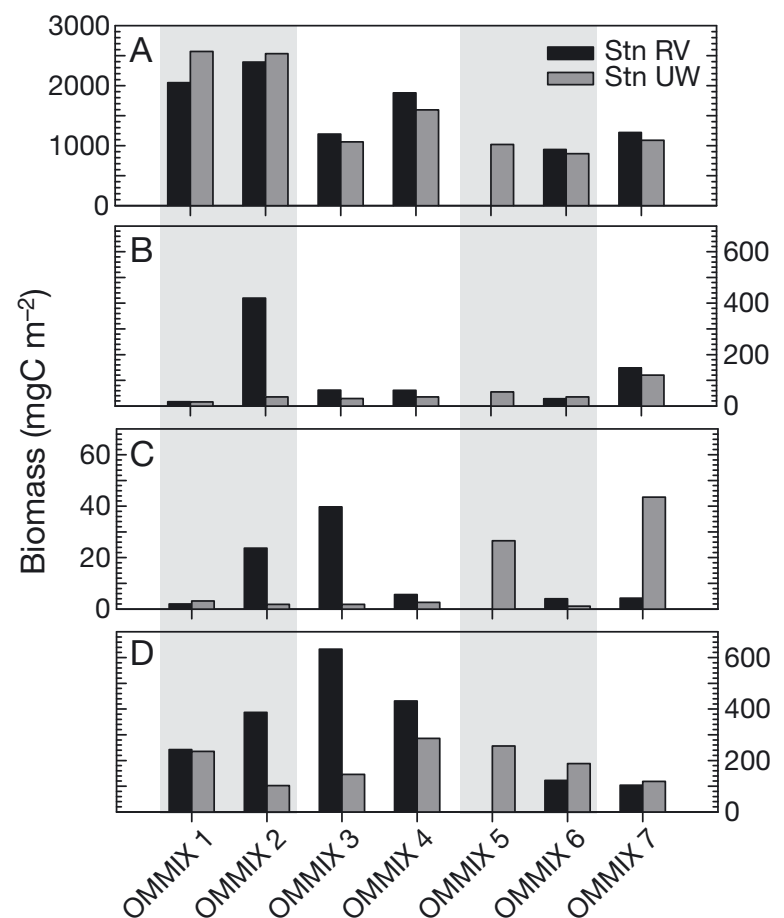

Fig. 5. Upper $20 \mathrm{~m}$ depth-integrated biomass of (A) bacterioplankton, (B) phototrophic, (C) mixotrophic, and (D) heterotrophic nanoflagellates during each sampling campaign (OMMIX 1-7) in the river plume area (Stn RV) and off Coliumo Bay (Stn UW). Shaded areas represent spring and white areas winter sampling periods
PNF biomass observed during OMMIX 2 (Fig. 5B). In winter, bacteria and PNF biomass were significantly higher at Stn RV (t-test, $\mathrm{p}<0.01$; Table 1$)$. In winter 2007, biomass values were higher for both MNF and HNF around the river plume (Stn RV; Fig. 5C,D).

\section{Ingestion rates}

There was always a background of small HNF for which FLB ingestion was rarely observed (80 to $90 \%$ ). Average flagellate ingestion rates determined during the different sampling periods varied between spring and winter (Fig. 6). MNF ingestion rates oscillated between 7.3 and 30.7 bact flag $^{-1} \mathrm{~h}^{-1}$, whereas HNF ingestion ranged from 2 to 7.5 bact flag $^{-1} \mathrm{~h}^{-1}$, and ingestion rate showed a better correlation with bacterial abundance for small mixotrophic

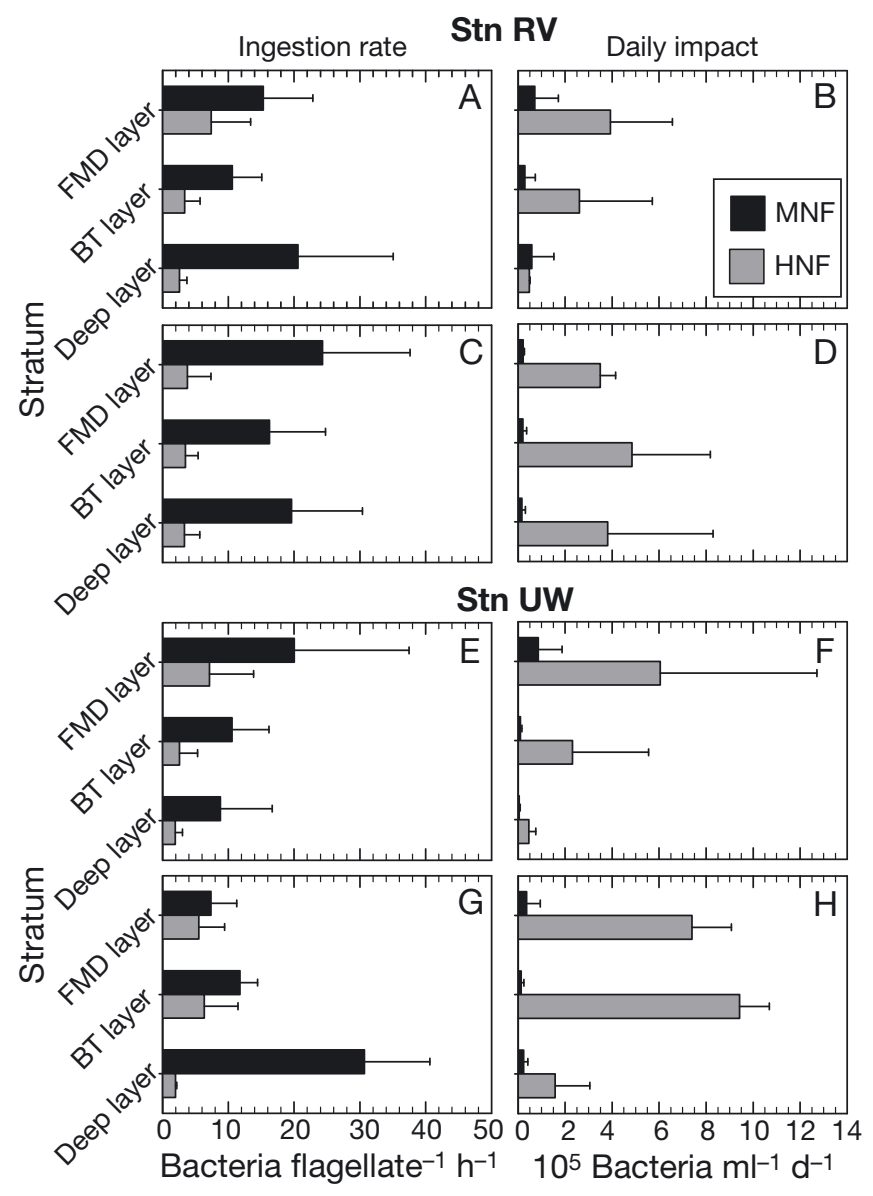

Fig. 6. Mean ( $\pm \mathrm{SD}$ ) ingestion rates (bacteria flagellate ${ }^{-1} \mathrm{~h}^{-1}$ ) and daily grazing impact on bacterioplankton (bacteria $\mathrm{ml}^{-1} \mathrm{~d}^{-1}$ ) determined through short uptake experiments of fluorescently labeled bacteria averaged for $(\mathrm{A}, \mathrm{B}, \mathrm{E}, \mathrm{F})$ spring and $(\mathrm{C}, \mathrm{D}, \mathrm{G}, \mathrm{H})$ winter at 2 sampling stations (Stns RV and UW).

MNF (HNF): mixotrophic (heterotrophic) nanoflagellates 


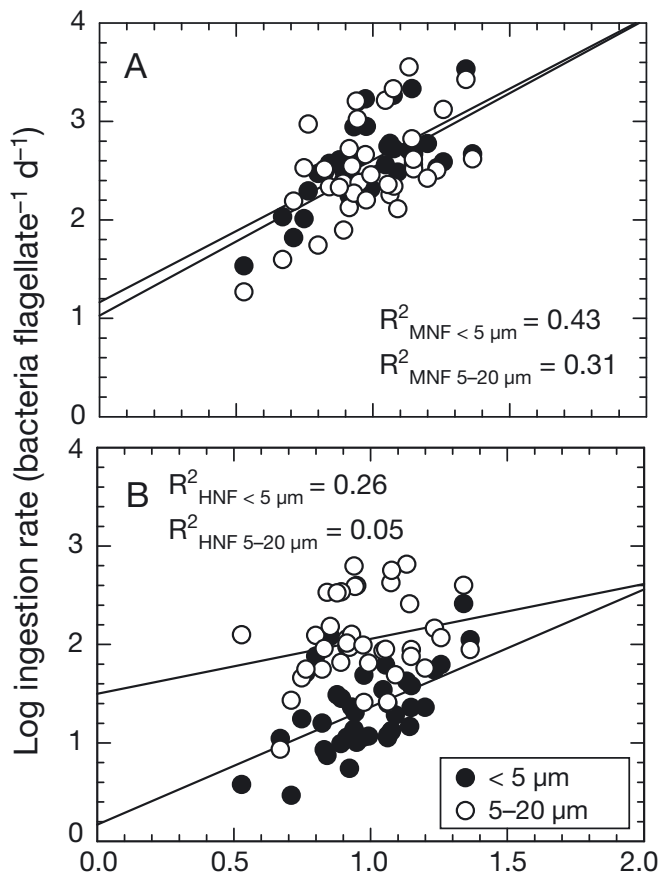

Log bacterial abundance $\left(\times 10^{5}\right.$ bacteria $\left.\mathrm{ml}^{-1}\right)$

Fig. 7. Relationship between log bacterial abundance $\left(\times 10^{5}\right.$ cells $\mathrm{ml}^{-1}$ ) and log ingestion rates (bacteria flagellate ${ }^{-1} \mathrm{~d}^{-1}$ ) of (A) mixotrophic and (B) heterotrophic nanoflagellates in 2 size categories: $<5 \mu \mathrm{m}$ and $5-20 \mu \mathrm{m}$

forms than those for heterotrophs (Fig. 7). However, in terms of daily impact, the trend was just the opposite due to the numerical dominance of HNF in the water column (Fig. 3E); in other words, grazing by HNF had a stronger effect. The highest ingestion rates (up to $\sim 30$ bact flag $^{-1} \mathrm{~h}^{-1}$ ) for MNF were found in winter. The daily grazing impact of MNF and HNF on the bacterioplankton communities ranged from $0.04 \times 10^{5}$ to $1 \times 10^{5}$ and from 0.5 to $9.4 \times 10^{5}$ bacteria $\mathrm{ml}^{-1} \mathrm{~d}^{-1}$, respectively. Bacterivory by MNF had the greatest impact on the standing stock in spring in the FMD layer at both sampling stations. On the other hand, the highest daily impact of HNF occurred in winter, mostly associated with the base of the thermocline. We also evaluated the degree of prey saturation by plotting the log-values of ingestion rates for phagotrophic nanoflagellates against the log-values of bacterial abundances (Fig. 7). A linear function described the relations better than an exponential model, and the best fits - according to the coefficient of determination $\left(R^{2}\right)$ - were found for MNF. A Spearman's rank correlation analysis between nanoflagellate ingestion and environmental variables, including bacterial abundance and production, showed that MNF ingestion by both size classes was significantly correlated with bacterial abun- dance, whereas ingestion by small HNF was also correlated with bacterial abundance but also negatively correlated with $\mathrm{N}$ :P ratio $(\mathrm{HNF}<5 \mu \mathrm{m})$ (Table 2$)$.

Carbon balances were made using ingestion rate data (Fig. 8A), assuming a gross growth efficiency of $32 \%$ (Straile 1997). Mixotrophs were assumed to be only $52 \%$ as efficient at fixing inorganic carbon as strict autotrophs (Hansen et al. 2000, Adolf et al. 2006), as determined by calculating their share of the total nanoplankton PP. Estimates of individual photosynthetic rates (Fig. 8B) showed that phototrophy made a more important contribution to the carbon acquisition of MNF in spring (Fig. 8C). In spring 2006 (OMMIX 2), when PNF and MNF peaked around the river plume, photosynthesis contributed little to the cell carbon balance in this area $\left(<1 \mathrm{pg} \mathrm{C} \mathrm{cell}^{-1} \mathrm{~h}^{-1}\right)$ (Fig. 8B). Heterotrophic carbon acquisition by cell ingestion varied widely throughout the study period, with the highest ingestion rates in spring 2006 and winter 2007 during OMMIX 1 and 4, respectively $(\sim 2$ to $4 \mathrm{pg} \mathrm{C} \mathrm{cell}^{-1} \mathrm{~h}^{-1}$ ) (Fig. 8A). However, on average, in winter, heterotrophy by MNF accounted for more than $80 \%$ of the carbon acquisition (Fig. 8C).

Integrated carbon ingestion by mixotrophic and heterotrophic forms showed that the highest carbon removal by mixotrophs occurred in spring 2006 at Stn RV $\left(27 \mathrm{mg} \mathrm{C} \mathrm{m}^{-2} \mathrm{~d}^{-1}\right)$ and in spring 2007 at Stn UW (15 mg C m ${ }^{-2} \mathrm{~d}^{-1}$ ). Similarly, heterotrophic forms also showed maximum carbon removal in spring. Nonetheless, the trend was the opposite, with maxima observed in spring 2007 at Stn RV (123 $\mathrm{mg} \mathrm{C} \mathrm{m}^{-2}$ $\mathrm{d}^{-1}$ ) and spring 2006 at Stn UW (133 $\mathrm{mg} \mathrm{C} \mathrm{m}^{-2} \mathrm{~d}^{-1}$ ) (Table 3).

Table 2. Spearman's rank correlation analyses between ingestion by mixotrophic (MNF) and heterotrophic (HNF) nanoflagellates and environmental variables. PAR: photosynthetically active radiation. ${ }^{*}$ : highly significant correlation. Assigned weights $>0.3$ are marked in bold. $\mathrm{n}=44$.

Data were $\log (x+1)$ transformed

\begin{tabular}{|c|c|c|c|c|}
\hline \multirow{2}{*}{$\begin{array}{l}\text { Physical/ } \\
\text { chemical variable }\end{array}$} & \multicolumn{4}{|c|}{ Trophic status/size class } \\
\hline & $\begin{array}{l}\text { MNF } \\
<5 \mu \mathrm{m}\end{array}$ & $\begin{array}{c}\text { MNF } \\
5-20 \mu \mathrm{m}\end{array}$ & $\begin{array}{c}\mathrm{HNF} \\
<5 \mu \mathrm{m}\end{array}$ & $\begin{array}{c}\text { HNF } \\
5-20 \mu \mathrm{m}\end{array}$ \\
\hline Temperature & 0.28 & 0.18 & 0.18 & 0.14 \\
\hline Salinity & -0.002 & -0.15 & 0.11 & -0.21 \\
\hline Oxygen & -0.12 & -0.13 & -0.07 & 0.18 \\
\hline PAR & -0.02 & -0.27 & 0.26 & 0.06 \\
\hline $\mathrm{NO}_{3}^{-}$ & -0.07 & -0.08 & 0.08 & -0.24 \\
\hline $\mathrm{NO}_{2}^{-}$ & 0.14 & 0.20 & -0.02 & 0.11 \\
\hline $\mathrm{PO}_{4}{ }^{3-}$ & -0.09 & 0.03 & -0.21 & -0.18 \\
\hline $\mathrm{N}: \mathrm{P}$ & -0.10 & 0.10 & $-0.36^{*}$ & -0.05 \\
\hline Bacterial abundance & $0.65^{*}$ & $0.50^{*}$ & $0.47^{*}$ & 0.18 \\
\hline Bacterial production & $-0.38^{*}$ & -0.28 & 0.003 & -0.08 \\
\hline River flow & 0.03 & 0.12 & -0.14 & 0.22 \\
\hline
\end{tabular}



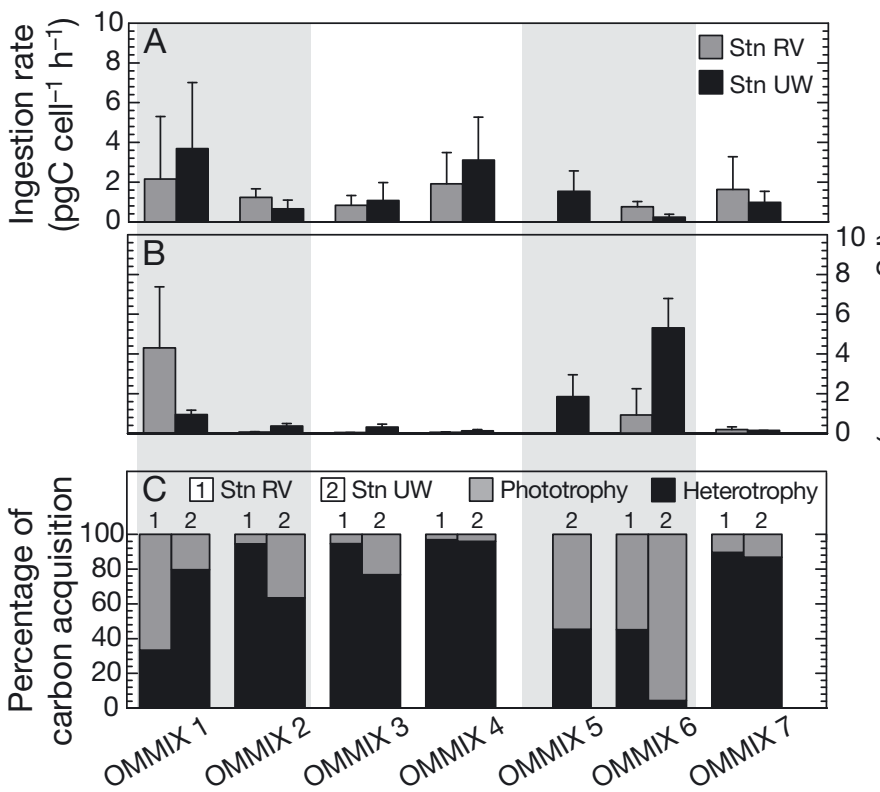

Fig. 8. (A) Individual ingestion rate (mean $\pm \mathrm{SD}$ pg $\mathrm{C}$ cell $^{-1} \mathrm{~h}^{-1}$ ), (B) individual photosynthetic rate (mean \pm SD; pg C cell ${ }^{-1} \mathrm{~h}^{-1}$ ), and (C) percentage of carbon acquisition, through phototrophy vs. heterotrophy during each sampling campaign (OMMIX 1-7) in the river plume area (Stn RV) and off Coliumo Bay (Stn UW). Shaded areas represent spring and white areas winter sampling periods

Table 3. Integrated carbon ingestion $\left(\mathrm{mg} \mathrm{C} \mathrm{m} \mathrm{m}^{-2} \mathrm{~d}^{-1}\right)$ by mixotrophic (MNF) and heterotrophic (HNF) nanoflagellates in the upper $20 \mathrm{~m}$ depth layer of the study area in spring and winter at both sampling stations

\begin{tabular}{|c|c|c|c|c|c|c|}
\hline & \multicolumn{3}{|c|}{ — Mixotrophs — } & \multicolumn{3}{|c|}{ — Heterotrophs_- } \\
\hline & $\begin{array}{l}\text { MNF } \\
<5 \mu \mathrm{m}\end{array}$ & $\begin{array}{c}\text { MNF } \\
5-20 \mu \mathrm{m}\end{array}$ & Total & $\begin{array}{l}\mathrm{HNF} \\
<5 \mu \mathrm{m}\end{array}$ & $\begin{array}{c}\text { HNF } \\
5-20 \mu \mathrm{m}\end{array}$ & Total \\
\hline \multicolumn{7}{|l|}{ Stn RV } \\
\hline Spring 2006 & 25 & 2 & 27 & 28 & 36 & 64 \\
\hline Winter 2007 & 4 & 3 & 7 & 40 & 14 & 54 \\
\hline Spring 2007 & 1 & 2 & 3 & 111 & 12 & 123 \\
\hline Winter 2008 & 5 & 3 & 8 & 18 & 16 & 34 \\
\hline \multicolumn{7}{|l|}{ Stn UW } \\
\hline Spring 2006 & 4 & 3 & 7 & 85 & 48 & 133 \\
\hline Winter 2007 & 7 & 5 & 12 & 23 & 20 & 43 \\
\hline Spring 2007 & 4 & 11 & 15 & 12 & 60 & 72 \\
\hline Winter 2008 & 1 & 1 & 2 & 18 & 14 & 32 \\
\hline
\end{tabular}

\section{DISCUSSION}

\section{Relative importance of different nanoflagellate forms under contrasting seasons}

Estimations of the contribution made by MNF bacterivores, in comparison with those of strictly heterotrophic nanoflagellates were, for years, an unknown 'black box' in river-influenced continental shelves and coastal upwelling carbon and food web models. The present study offers the first evaluation of the role of PNF, MNF, and HNF communities in a riverinfluenced eutrophic coastal ecosystem. Although limited in terms of spatial coverage, we herein show the spatial heterogeneity between 2 sampling sites influenced by different oceanographic processes (i.e. river runoff and coastal upwelling). Bacterial production at this coastal upwelling area off Central Chile measured in other studies and from other coastal upwelling areas, fit well with our estimations, e.g. from 19.2 to $33.6 \mathrm{mg} \mathrm{C} \mathrm{m}^{-3} \mathrm{~d}^{-1}$ in a coastal upwelling site off Central Chile (McManus \& Peterson 1988), 4 to $92 \mathrm{mg} \mathrm{C} \mathrm{m}^{-3} \mathrm{~d}^{-1}$ in Benguela (Lucas et al. 1984), and 2.7 to $22.2 \mathrm{mg} \mathrm{C} \mathrm{m}^{-3} \mathrm{~d}^{-1}$ in the NW Iberian margin (Barbosa et al. 2001). Typically, bacteria have been shown to rapidly respond to the pulsed production cycles typical of upwelling areas (McManus \& Peterson, 1988). However, many studies have also shown enhanced bacterial heterotrophic activities in river plume areas worldwide. For instance, Albright (1983) observed the stimulation of bacterial activity when river waters entered the salty surface waters of the Strait of Georgia in British Columbia, Canada. Carlsson et al. (1995) noted that humic substances from river discharge may enhance the abundance of bacterial grazers in river mouths, as reflected in increased bacterial production.

High abundances of pico- and nanophytoplankton have also been reported in river plume areas. The present study evidenced higher nanophytoplankton PP in the river plume area. Similarly, high abundances of picophytoplankton, picoeukaryotes (Liu et al. 2004), and nanophytoplankton (Jochem 2003) have been observed in river plumes. Recently, Christaki et al. (2009) showed that the PNF abundance was 3 to 5 fold higher in the Rhone River plume waters compared to marine waters. Abundances of PNF and HNF were within the ranges reported in other studies of oligotrophic, mesotrophic, and eutrophic marine ecosystems, mostly from 0.1 to 30 cells ml ${ }^{-1} \times 10^{3}$ (Table 4 and references in there). We did not observe a clear upwelling vs. nonupwelling trend for PNF abundance or biomass, contrasting with the summer peaks of PNF abundance observed by Böttjer \& Morales (2007) at a coastal upwelling site off central Chile. In a study of the annual cycle of nanoflagellates in the central Cantabrian Sea, Granda \& Anadón (2008) also reported the highest abundance during summer upwelling periods. Although the PNF biomass in our study was substantially higher in spring 2006 (OMMIX 2), it was relatively low in spring 2007. In 


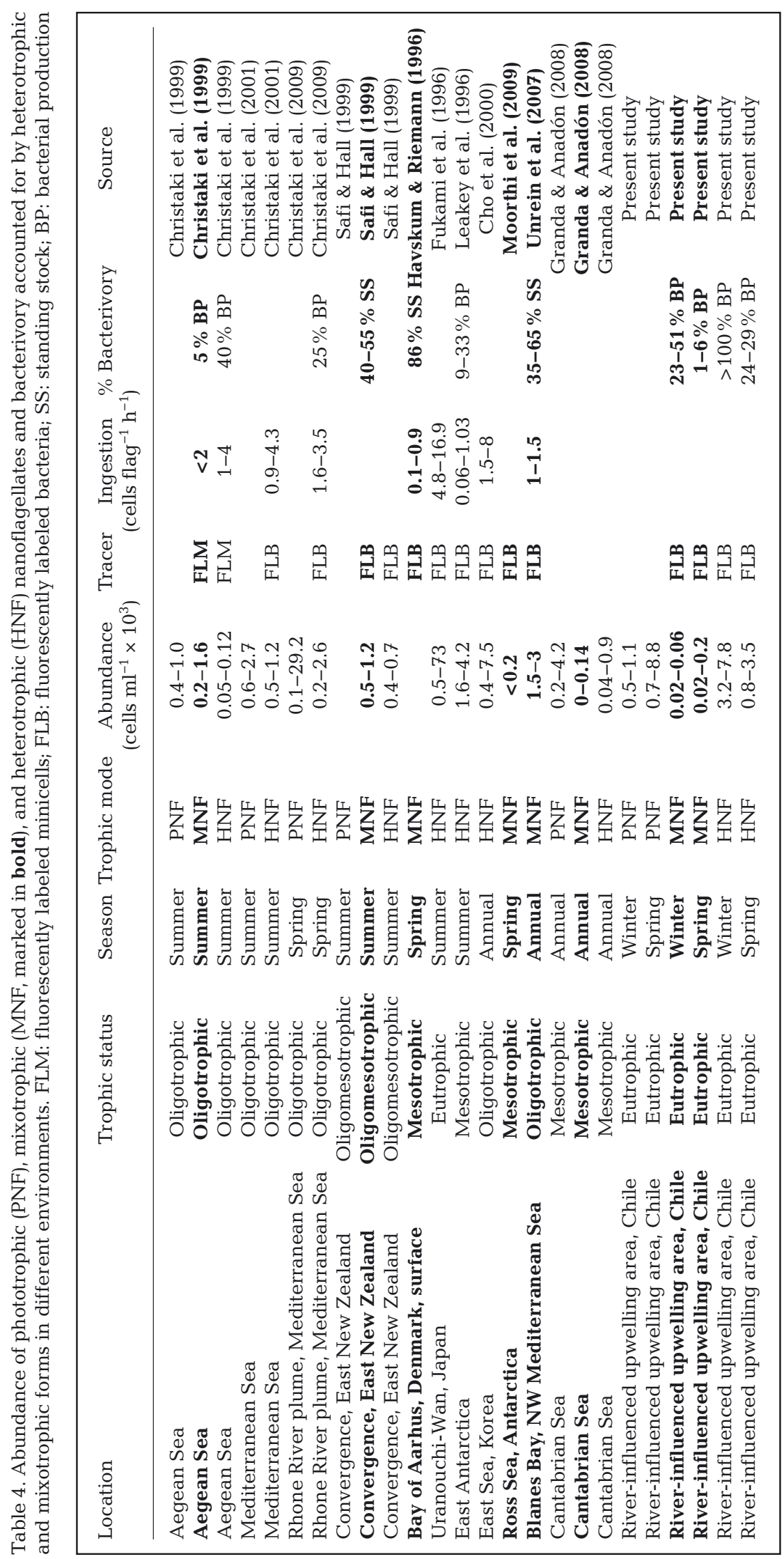

contrast, nanophytoplankton PP always showed a clear seasonal trend, being higher in spring. The lack of a clear seasonal trend in PNF abundance and biomass implies that, despite higher growth rates in spring-summer (i.e. high $\mathrm{PP})$, the PNF abundance was tightly controlled by grazers (e.g. ciliates and dinoflagellates grazing was estimated during the same field surveys by Vargas \& Martínez 2009). These grazers fail to reveal a contrasting seasonal trend between winter and spring.

During the present study, average MNF abundances were $<200$ cells $\mathrm{ml}^{-1}$, a close fit to those values reported by Granda \& Anadón (2008) for the Cantabrian Sea and by Moorthi et al. (2009) for the Ross Sea, Antarctica, both mesotrophic environments (Table 4). However, the use of similar FLB uptake measurements in more oligotrophic environments (Aegean Sea, NW Mediterranean Sea, East New Zealand) has revealed larger MNF abundances, from 200 to 3000 cells ml$^{-1}$ (e.g. Christaki et al. 1999, Safi \& Hall 1999, Unrein et al. 2007).

An important preliminary implication of these results is that MNF seem to be lower in terms of abundance in highly productive coastal environments, as compared to more mesotrophic and/or oligotrophic environments (e.g. Mediterranean Sea). The relative abundance of MNF as a percentage of total bacterivorous and photosynthetic nanoflagellates in our study averaged from 1 to $6 \%$ and from 2 to $6 \%$, respectively, which contrasts with the higher contribution found in other studies. For instance, Moorthi et al. (2009) reported that MNF comprised 8 to $42 \%$ of bacterivorous nanoflagellates in the water column of Ross Sea. However, if we consider the feeding-inactive 


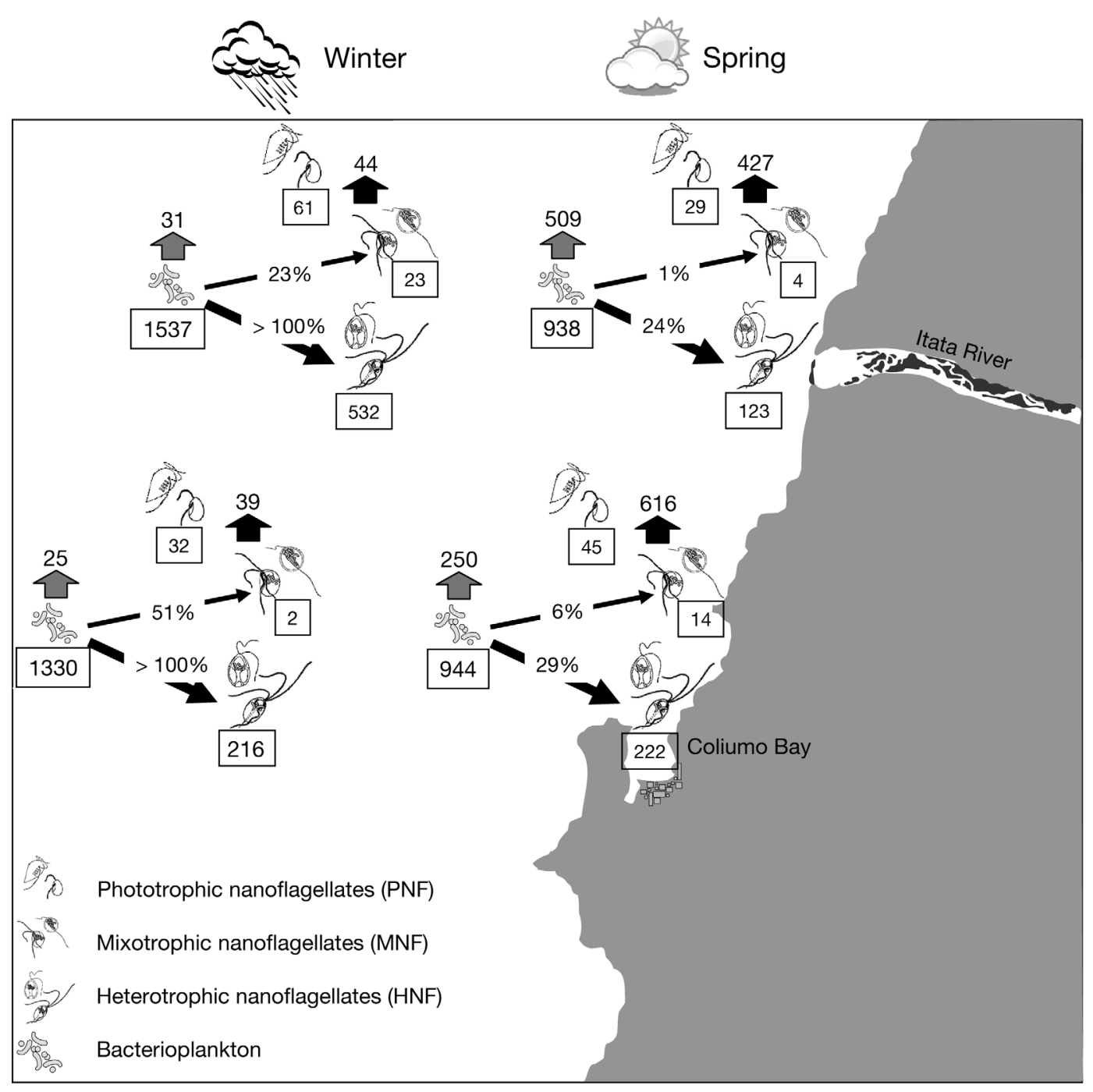

Fig. 9. Carbon fluxes in winter and spring 2007 between bacterioplankton and nanoflagellates (PNF, MNF, HNF), and for the Itata River plume area (Stn RV) and off Coliumo Bay (Stn UW). Numbers inside the boxes show upper $20 \mathrm{~m}$ depth-integrated biomass for each group (mg $\mathrm{C} \mathrm{m}^{-2}$ ); numbers above the wide grey and black arrows show bacterial production (BP) and nanophytoplankton primary production (PP) (both in $\mathrm{mg} \mathrm{C} \mathrm{m}^{-2} \mathrm{~d}^{-1}$ ), respectively. The percentage in parentheses (\%) on the thin arrows represents the percentage of BP consumed per day

cryptophytes in the mixotrophic compartment (i.e. actively grazing HNF are defined as those ingesting any bacteria during uptake experiments; Cho et al. 2000), we may have misclassified a large fraction of the actual MNF as PNF and affected our ability to identify seasonal trends in mixotrophic behavior. In fact, inactive grazers are a common phenomenon in feeding experiments (e.g. Schmidtke et al. 2006), leading to underestimations of mixotroph abundance and overestimations of phototrophic forms. Furthermore, the mixotrophs were identified based on their FLB uptake, and many studies in the literature report discrimination against FLB compared to living bacteria (e.g. Landry et al. 1991), and in particular against motile bacteria (González et al.1993). Our data also showed that HNF reached a higher biomass than strictly plastidic flagellates and were numerically dominant in terms of biomass in winter around the river plume. Relatively higher HNF abundance and biomass in river plumes may have been conditioned by higher bacterial production occurring there. Consequently, the dominance of river-induced conditions in winter (e.g. stratification, nutrients, DOM fluxes) may also lead to a sustained high heterotrophic and pico- and nanophytoplankton biomass. 


\section{Environmental factors affecting nanoflagellate abundance and bacterivory}

Carbon balances were calculated by assuming that mixotrophs were only $50 \%$ as efficient at fixing inorganic carbon as strict autotrophs (Skovgaard 1999, Adolf et al. 2006). This assumption was based on an average from values reported in studies dealing with individual photosynthetic measurements in dinoflagellates, since to our knowledge, there are no reports on individual photosynthetic rates measured simultaneously for both MNF and PNF. For instance, Hansen et al. (2000) found that the mixotrophic dinoflagellate Fragilidium subglobosum can reduce its photosynthetic performance to about $40 \%$ of that found in phototrophic cultures. Photosynthetic performance in Karlodinium micrum was around 52\% lower during mixotrophic growth than during autotrophic growth (Adolf et al. 2006). Finally, Skovgaard (1999) also found that photosynthetic rate was reduced by approximately $50 \%$ in mixotrophic dinoflagellates as compared with cells growing strictly photosynthetically. Marshall \& Laybourn-Parry (2002) also calculated individual photosynthetic rates and grazing and photosynthesis contributions to the carbon balance in ambient mixotrophic cryptophytes communities by using an approach similar to ours. However, Marshall \& Laybourn-Parry (2002) did not report any information regarding how primary production was shared between MNF and PNF, and the photosynthetic efficiency they considered for photosynthesis estimates in mixotrophic forms. Consequently, we assume that small flagellates could reduce their autotrophic efficiency at least for an average of $50 \%$ as done by larger flagellate organisms. Of course, this is a gross estimation assuming a similar efficiency for small flagellates, but additionally, we have not considered that contributions of photosynthesis and phagotrophy also depend on the type of mixotrophy (Stickney et al. 2000). Indeed these estimates should be an important issue for research on the role of mixotrophic nanoflagellate communities in marine ecosystems. Based on these assumptions, carbon balances for mixotrophs showed that, in winter, heterotrophy could contribute most of carbon acquisition (from $\sim 75$ to $95 \%$ heterotrophic carbon gain). It also makes sense that phototrophy would become less important in river plume waters in winter, as these waters typically carry sediments from river runoff in this region (Araneda et al. 2009), with the subsequent reduction in light availability at depth. Therefore, although dissolved $\mathrm{PO}_{4}{ }^{3-}$ concentrations were usually low in the surface layer, we as- sumed that the main benefit of mixotrophy (observed in winter) was carbon and energy acquisition in an environment of reduced PAR. This agrees with other reports of MNF from other coastal ecosystems with reduced PAR (e.g. Marshall \& Laybourn-Parry 2002, Hammer \& Pitchford 2006, Czypionka et al. 2010).

Water temperature and prey abundance are usually some of the most important factors regulating HNF phagotrophic activity (Choi 1994, Vaqué et al. 1994). Positive correlation between bacterial abundance and MNF and HNF ingestion evidence this strong dependence (Table 2). However, bacterial abundance is not the best measure of prey availability since it is well known that HNF may use alternative food resources other than heterotrophic bacteria, e.g. picocyanobacteria, picoeukaryotes, or detritus, although they usually do so at lower rates (Kuosa 1991, Sanders et al. 2000, Sherr \& Sherr 2002). Ingestion by small HNF was also negatively correlated with N:P ratio, which suggests an increase in bacterivory activity under $\mathrm{PO}_{4}{ }^{3-}$ low conditions. Support for this explanation is also found in a study by Nygaard \& Tobiesen (1993) who also found higher HNF ingestion rates in P-limited conditions. In addition to bottom-up factors, HNF abundance could also be controlled by top-down processes. For instance, Vargas \& Martinez (2009), evaluated the grazing impact of ciliates and dinoflagellates on nanoflagellate communities during the same experimental and field surveys as in the present study. Those authors clearly showed maximum carbon ingestion by dinoflagellates and ciliates while grazing on nanoflagellates in spring. Furthermore, the ingestion rate of small copepods evaluated during the same surveys evidenced that HNF may constitute an important component of copepod diet in spring (C. A. Vargas unpubl. data), resulting in a strong top-down control on HNF populations, similar to that found in other coastal ecosystems (Goericke 2002).

\section{Mixotrophic nanoflagellates in carbon and food web models of coastal ecosystem}

To the best of our knowledge, this is the first comparative measurement of bacterivory rates by the HNF and MNF inhabiting one of the world's most productive, river-influenced, coastal upwelling ecosystems. Since the photic layer ranged between 20 and $25 \mathrm{~m}$ depth during our study, biomass and rate measurements were integrated between 0 and $20 \mathrm{~m}$ depth to construct a mean carbon budget for each sampling season in 2007 and to evaluate the role that 
mixotrophic forms may play in the microbial food web of a productive, river-influenced coastal upwelling site. Calculations of grazing pressure showed that MNF could be capable of removing between 23 and $51 \% \mathrm{BP} \mathrm{d}^{-1}$ in winter and from 1 to $6 \% \mathrm{BP} \mathrm{d}^{-1}$ in spring, with a higher grazing impact at Stn UW, since $\mathrm{BP}$ and bacterial biomass were substantially lower at this site than in the river plume area, which is commonly subsidized by terrestrial organic sources (Vargas \& Martinez 2009; Table 1). Consequently, in the microbial food web, HNF controlled BP by removing a major fraction of $\mathrm{BP}$ in spring (24 to $29 \% \mathrm{BP} \mathrm{d}^{-1}$ ) and $>100 \% \mathrm{BP} \mathrm{d}^{-1}$ in winter, mainly due to the low BP at that time (Fig. 9). Finally, phototrophic and mixotrophic nanoflagellate forms contributed $44 \mathrm{mg}$ $\mathrm{C} \mathrm{m}^{-2} \mathrm{~d}^{-1}$ of PP in winter at Stn RV, as compared to only $39 \mathrm{mg} \mathrm{C} \mathrm{m}^{-2} \mathrm{~d}^{-1}$ at Stn UW. In winter 2007, nanoplankton PP contributed between 20 and $40 \%$ of the total PP around the river plume (Iriarte et al. in press).

The specific grazing rates estimated in the present study are in the same range as those reported for other coastal areas worldwide (see Table 4 and references therein), where heterotrophic and mixotrophic nanoflagellates accounted for a substantial proportion of total bacterivory. For instance, Leakey et al. (1996) reported that 9 to $33 \%$ of the BP was grazed daily by HNF in the Ross Sea, Antarctica. Safi \& Hall (1999) estimated that 40 to $55 \%$ of the bacterioplankton standing stock was grazed by MNF, whereas Christaki et al. (1999) reported that $\sim 40 \% \mathrm{BP} \mathrm{d}^{-1}$ was grazed by HNF and only $5 \% \mathrm{BP} \mathrm{d}^{-1}$ by MNF. Similar to these reports, bacterivory in our study also appeared to be dominated by HNF rather than MNF. Previous investigations in coastal upwelling areas have only considered the top-down effect of HNF grazing. Vargas et al. (2007) constructed a conceptual model of the carbon flow from the estimated PP on the continental shelf off central Chile. With this model, the authors clearly showed that HNF were able to graze $>90 \% \mathrm{BP} \mathrm{d}^{-1}$ in winter, whereas in summer, HNF were able to graze $\sim 70 \% \mathrm{BP} \mathrm{d}^{-1}$.

It is clear from many studies worldwide that grazing by HNF and MNF can control bacterioplankton biomass by removing a substantial fraction of BP (Zubkov \& Tarran 2008). Moreover, nanoflagellates are widely recognized as important prey items for protozooplankton, including dinoflagellates and ciliates, in coastal areas (e.g. Vargas \& Martínez 2009), which makes these protozoans direct competitors with copepods and other mesozooplankton (Vargas et al. 2007). Through this link, bacterivory by MNF and HNF can make autochthonous organic carbon from algal exudates and allochthonous organic carbon from riverine DOC indirectly available to zooplankton and upper trophic levels (see Calbet \& Saiz 2005). MNF might also account for $\sim 1$ to $5 \%$ of the nanoplankton $\mathrm{PP}$, a percentage that needs to be incorporated into food web models of productive coastal ecosystems. Consequently, our results reinforce the idea that, through grazing by MNF and HNF, the microbial pathway may increase yields of both terrestrial (detrital DOC) and photosynthetically fixed organic carbon, supporting higher secondary production of larger metazoans than would be expected from a simple herbivore-dominated food chain in coastal areas.

Acknowledgements. We thank the captains and crew of the research vessel LC 'Kay Kay' and the OMMIX team who participated in our cruises (especially R. Martinez, R. Bermudez, C. Valenzuela, and D. Opazo). We thank J. Turner for English editing of the manuscript. We are also indebted to R. Escribano (COPAS Center) for providing all the logistics facilities at the Marine Research Station of Dichato and on board the LC 'Kay Kay', Universidad de Concepción (e.g. CTDO, Tucker trawl nets, Niskin bottles, etc.) and for providing the PAR data. We also acknowledge F. Tapia (COPAS Center) for statistical advice. Financial support for this study was fully provided by FONDECYT projects No. 1060709 to C.A.V. and J.L.I. and No. 1095069 to C.A.V.

\section{LITERATURE CITED}

Adolf JE, Stoecker DK, Harding LW Jr (2006) The balance of autotrophy and heterotrophy during mixotrophic growth of Karlodinium micrum (Dinophyceae). J Plankton Res 28:737-751

> Albright LJ (1983) Heterotrophic biomasses, activities and productivities within the Fraser river plume. Can J Fish Aquat Sci 40:s216-220

Andersen P, Fenchel T (1985) Bacterivory by microheterotrophic flagellates in seawater samples. Limnol Oceanogr 30:198-202

Araneda AE, Martínez C, Urrutia R (2009) Sedimentos del Río Itata y Área Marina Adyacente. In: Parra O, Castilla JC, Quiñones R, Camaño A (eds) La cuenca hidrográfica del Río Itata. Editorial Universidad de Concepción, Concepción, p 59-99

> Azam F, Fenchel T, Field JG, Gray JS, Meyer-Reil LA, Thingstad DF (1983) The ecological role of water-column microbes in the sea. Mar Ecol Prog Ser 10:257-263

Barbosa AB, Galväo HM, Mendes PA, Álvarez-Salgado XA, Figueiras FG, Joint I (2001) Short-term variability of heterotrophic bacterioplankton during upwelling off the NW Iberian margin. Prog Oceanogr 51:339-359

> Bennett SJ, Sanders RW, Porter KG (1990) Heterotrophic, autotrophic, and mixotrophic nanoflagellates: seasonal abundances and bacterivory in a eutrophic lake. Limnol Oceanogr 35:1821-1832

Bjørnsen PK (1986) Bacterioplankton growth yield in continuous seawater cultures. Mar Ecol Prog Ser 30:191-196 
Böttjer D, Morales CA (2007) Nanoplanktonic assemblages in the upwelling area off Concepción $\left(\sim 36^{\circ} \mathrm{S}\right)$, Central Chile: abundance, biomass, and grazing potential during the annual cycle. Prog Oceanogr 75:415-434

> Calbet A, Saiz E (2005) The ciliate-copepod link in marine ecosystems. Aquat Microb Ecol 38:157-167

> Carlsson P, Granéli E, Tester P, Boni L (1995) Influences of riverine humic substences on bacteria, protozoa, phytoplankton, and copepods in a coastal plankton community. Mar Ecol Prog Ser 127:213-221

Cho B, Na ChS, Choi DH (2000) Active ingestion of fluorescently labeled bacteria by mesopelagic heterotrophic nanoflagellates in the East Sea, Korea. Mar Ecol Prog Ser 206:23-32

> Choi JW (1994) The dynamic nature of protistan ingestion response to prey abundance. J Eukaryot Microbiol 41: 137-146

> Christaki U, Wambeke FV, Dolan JR (1999) Nanoflagellates (mixotrophs, heterotrophs and autotrophs) in the oligotrophic eastern Mediterranean: standing stocks, bacterivory and relationships with bacterial production. Mar Ecol Prog Ser 181:297-307

> Christaki U, Giannakourou A, Van Wambeke F, Grégori G (2001) Nanoflagellate predation on auto- and heterotrophic picoplankton in the oligotrophic Mediterranean Sea. J Plankton Res 23:1297-1310

> Christaki U, Courties C, Joux F, Jeffrey WH, Neveux J, Naudin JJ (2009) Community structure and trophic role of ciliates and heterotrophic nanoflagellates in Rhone River diluted mesoscale structures (NW Mediterranean Sea). Aquat Microb Ecol 57:263-277

Cole J, Pace M, Findlay S (1988) Bacterial production in fresh and saltwater ecosystems: a cross system overview. Mar Ecol Prog Ser 43:1-10

> Czypionka T, Vargas CA, Silva N, Daneri G, González H, Iriarte JL (2011) Importance of mixotrophic nanoplancton in Aysén Fjord (Southern Chile) during austral winter. Cont Shelf Res 31:216-224

Dagg M, Benner R, Lohrenz S, Lawrence D (2004) Transformation of dissolved and particulate materials on continental shelves influenced by large rivers: plume processes. Cont Shelf Res 24:833-858

> Fuhrman JA, Azam F (1982) Thymidine incorporation as a measure of heterotrophic bacterioplankton production in marine surface waters: evaluation and field results. Mar Biol 66:109-120

Fukami K, Murata N, Morio Y, Nishijima T (1996) Distribution of heterotrophic nanoflagellates and their importance as the bacterial consumer in a eutrophic coastal seawater. J Oceanogr 52:399-407

> Goericke R (2002) Top-down control of phytoplankton biomass and community structure in the monsoonal Arabian Sea. Limnol Oceanogr 47:1307-1323

González JM, Iriberri J, Egea L, Barcina I (1990) Differential rates of digestion of bacteria by freshwater and marine phagotrophic protozoa. Appl Environ Microbiol 56: 1851-1857

González JM, Sherr EB, Sherr BF (1993) Differential feeding by marine flagellates on growing versus starving, and on motile versus nonmotile bacterial prey. Mar Ecol Prog Ser 102:257-267

Granda AP, Anadón R (2008) The annual cycle of nanoflagellates in the central Cantabrian Sea (Bay of Biscay). J Mar Syst 72:298-308

Haas LW (1982) Improved epifluorescent microscopic tech- nique for observing planktonic microorganisms. Ann Inst Oceanogr 58:261-266

> Hammer AC, Pitchford JW (2006) Mixotrophy, allelopathy and the population dynamics of phagotrophic algae (cryptophytes) in the Darss Zingst Bodden estuary, southern Baltic. Mar Ecol Prog Ser 328:105-115

> Hansen PJ, Skovgaard A, Glud RN, Stoecker DK (2000) Physiology of the mixotrophic dinoflagellate Fragilidium subglobosum. II. Effects of time scale and prey concentration on photosynthetic performance. Mar Ecol Prog Ser 201:137-146

> Havskum H, Riemann B (1996) Ecological importance of bacterivorous, pigmented flagellates (mixotrophs) in the Bay of Aarhus, Denmark. Mar Ecol Prog Ser 137:251-263

> Hernández KL, Quiñones RA, Daneri G, Helbling EW (2006) Effects of solar radiation on bacterioplankton production in the upwelling system off central-southern Chile. Mar Ecol Prog Ser 315:19-31

Iriarte JL, González HE (2004) Phytoplankton size structure during and after the 1997/98 El Niño in a coastal upwelling area of the northern Humboldt Current System. Mar Ecol Prog Ser 269:83-90

Iriarte JL, Vargas CA, Urrutia RE, Tapia FJ (in press) Primary production and plankton carbon biomass in a riverinfluenced upwelling area off Concepción, Chile. Prog Oceanogr 92-95:97-109

Jochem FJ (2003) Photo- and heterotrophic pico- and nanoplankton in the Mississippi River plume: distribution and grazing activity. J Plankton Res 25:1201-1214

> Jost C, Lawrence CA, Campolongo F, van de Bund W, Hill S, DeAngelis DLD (2004) The effects of mixotrophy on the stability and dynamics of a simple planktonic food web model. Theor Popul Biol 66:37-51

Kuosa H (1991) Picoplanktonic algae in the northern Baltic Sea: seasonal dynamics and flagellate grazing. Mar Ecol Prog Ser 73:269-276

> Landry MR, Lehner-Fournier JM, Sundstrom JA, Fagerness VL, Selp SE (1991) Discrimination between living and heat-killed prey by a marine zooflagellate, Paraphysomomnas vestita (Stokes). J Exp Mar Biol Ecol 146: $139-151$

Laybourn-Parry J, Parry J (2000). Flagellates and the microbial loop. In: Leadbeater BSC, Green JC (eds) The flagellates: unity, diversity and evolution. Taylor \& Francis, London, p 216-239

> Leakey RJ, Archer SD, Grey J (1996) Microbial dynamics in coastal waters of East Antarctica: bacteria production and nanoflagellate bacterivory. Mar Ecol Prog Ser 142: 3-17

> Lee S, Fuhrman JA (1987) Relationships between biovolume and biomass of naturally derived marine bacterioplankton. Appl Environ Microbiol 53:1298-1303

> Liu H, Michael D, Campbell L, Urban-Rich J (2004) Picophytoplankton and bacterioplankton in the Mississippi River plume and its adjacent waters. Estuaries 27: $147-156$

Lucas MI, Painting SJ, Muir DG (1984) Estimates of carbon flow through bacterioplankton in the Benguela upwelling region based on ${ }^{3} \mathrm{H}$-thymidine incorporation and predator free-incubations. IFREMER Actes Colloq 3: 375-383

Manly BF (1997) Randomization, bootstrap and Monte Carlo methods in biology, 2nd edn. Chapman \& Hall/CRC, New York, NY

Marie D, Partensky F, Jacquet S, Vaulot D (1997) Enumera- 
tion and cell cycle analysis of natural populations of marine picoplankton by flow cytometry using the nucleic acid stain SYBR Green I. Appl Environ Microbiol 63: 186-193

Marshall W, Laybourn-Parry J (2002) The balance between photosynthesis and grazing in Antartic mixotrophic cryptophytes. Freshw Biol 47:2060-2070

McManus GB, Peterson WT (1988) Bacterioplankton production in the nearshore zone during upwelling off central Chile. Mar Ecol Prog Ser 43:11-17

Montero P, Daneri G, Cuevas LA, González HE, Jacob B, Lizárraga L, Menschel E (2007) Productivity cycles in the coastal upwelling area off Concepción: the importance of diatoms and bacterioplankton in the organic carbon flux. Prog Oceanogr 75:518-530

Moorthi SD, Caron DA, Gast R, Sanders RW (2009) Mixotrophy: a widespread and important ecological strategy for planktonic and sea-ice nanoflagellates in the Ross Sea, Antarctica. Aquat Microb Ecol 54:269-277

> Nygaard K, Tobiesen A (1993) Bacterivory in algae: a survival strategy during nutrient limitation. Limnol Oceanogr 38:273-279

Parsons TR, Maita Y, Lalli CM (1984) Manual of chemical and biological methods for seawater analysis. Pergamon Press, Oxford

Pomeroy LR (1974) The Ocean's food web: a changing paradigm. Bioscience 24:499-504

Safi KA, Hall JA (1999) Mixotrophic and heterotrophic nanoflagellate grazing in the convergence zone east of New Zealand. Aquat Microb Ecol 20:83-93

Sánchez GE, Pantoja S, Lange CB, González HE, Daneri G (2008) Seasonal changes in particulate biogenic and lithogenic silica in the upwelling system off Concepción $\left(\sim 36^{\circ} \mathrm{S}\right)$, Chile, and their relationship to fluctuations in marine productivity and continental input. Cont Shelf Res 28:2594-2600

Sanders RW (1991) Mixotrophic protists in marine and freshwater ecosystems. J Protozool 38:76-81

Sanders RW, Berninger UG, Lim EL, Kemp PF, Caron DA (2000) Heterotrophic and mixotrophic nanoplankton predation on picoplankton in the Sargasso Sea and on Georges Bank. Mar Ecol Prog Ser 192:103-118

Schmidtke A, Bell EM, Weithoff G (2006) Potential grazing impact of the mixotrophic flagellate Ochromonas sp. (Chrysophyceae) on bacteria in an extremely acidic lake. J Plankton Res 28:991-1001

Sherr EB, Sherr BF (1994) Bacterivory and herbivory: key roles of phagotrophic protists in pelagic food webs. Microb Ecol 28:223-235

Sherr EB, Sherr BF (2002) Significance of predation by protists in aquatic microbial food webs. Antonie van Leeuwenhoek 81:293-308

Sherr BF, Sherr EB, Fallon RD (1987) Use of monodispersed, fluorescently labelled bacteria to estimate in situ proto-

Editorial responsibility: Daniel Vaulot,

Roscoff, France zoan bacterivory. Appl Environ Microbiol 53:958-965

Simon M, Azam F (1989) Protein content and protein synthesis rates of planktonic marine bacteria. Mar Ecol Prog Ser 51:201-213

Skovgaard A (1999) Physiological aspects of mixotrophy in dinoflagellates. PhD thesis, Marine biology laboratory, Copenhagen University

Steemann-Nielsen E (1952) The use of radioactive carbon $\left({ }^{14} \mathrm{C}\right)$ for measuring organic production in the sea. J Cons Perm Int Explor Mer 18:117-140

Stickney HL, Hood RR, Stoecker DK (2000) The impact of mixotrophy on planktonic marine ecosystems. Ecol Model 125:203-230

Straile D (1997) Gross growth efficiencies of protozoan and metazoan zooplankton and their dependence on food concentration, predator-prey weigth ratio, and taxonomic group. Limnol Oceanogr 42:1375-1385

Strickland JDH, Parsons TR (1968) Determination of reactive nitrite. In: A practical handbook of seawater analysis. Bull Fish Res Board Can 167:71-75

Troncoso VA, Daneri G, Cuevas LA, Jacob B, Montero P (2003) Bacterial carbon flow in the Humboldt Current System off Chile. Mar Ecol Prog Ser 250:1-12

Tsai A, Chiang K, Chan Y, Lin Y, Chang J (2007) Pigmented nanoflagellates in the coastal western subtropical Pacific are important grazers on Synechococcus populations. J Plankton Res 29:71-77

> Unrein F, Massana R, Alonso-Sáez L, Gasol JM (2007) Significant year-round effect of small mixotrophic flagellates on bacterioplankton in an oligotrophic coastal system. Limnol Oceanogr 52:456-469

> Vaqué D, Gasol JM, Marrasé C (1994) Grazing rates on bacteria: the significance of methodology and ecological factors. Mar Ecol Prog Ser 109:263-274

> Vargas CA, Martinez RA (2009) Grazing impact of natural populations of ciliates and dinoflagellates in a riverinfluenced continental shelf. Aquat Microb Ecol 56: 93-108

Vargas CA, Martínez RA, Cuevas LA, Pavez M, and others (2007) The relative importance of microbial and classical food webs in a highly productive coastal upwelling area. Limnol Oceanogr 52:1495-1510

Vargas CA, Martínez RA, Escribano R, Lagos NA (2010) Seasonal relative influence of food quantity, quality, and feeding behaviour on zooplankton growth regulation in coastal food webs. J Mar Biol Assoc U K 90:1189-1201

Verity PG, Robertson CY, Tronzo CR, Andrews MG, Nelson JR, Sieracki ME (1992) Relationships between cell volume and the carbon and nitrogen content of marine photosynthetic nanoplankton. Limnol Oceanogr 37: 1434-1446

Zubkov MV, Tarran GA (2008) High bacterivory by the smallest phytoplankton in the North Atlantic Ocean. Nature 455:224-226

Submitted: September 12, 2011; Accepted: January 4, 2012 Proofs received from author(s): February 19, 2012 